\title{
TO 'RAISE AND QUELL': \\ THE EMOTIONAL PULSE
} \author{
$\begin{array}{ll}\text { Judy Tarling } & \text { 1. Associate Royal } \\ \text { Academy of Music, }\end{array}$ \\ London. Email: judytar- \\ ling@btinternet.com.
}

\begin{abstract}
This article describes the importance of rhythm in controlling the emotional state of the listener. Rhythmic impulses originate in the human body, through movement and speech. The ancient writers and orators noted how different rhythms in speech could affect the feelings of an audience. When rhetoric began to influence musical composition in the 16th century, composers were quick to realize the potential for expressing emotion by using various rhythmic devices borrowed from speech patterns. The manner of performance also influences the way these devices are received by the listener.
\end{abstract}

KEYWORDS: Musical rhetoric; Rhythm; Musical performance

\section{"PROVOCAR E ACALMAR": O PULSO RÍTMICO EMOCIONAL}

RESUMO: Este artigo discorre sobre a importância do ritmo no controle das disposiçóes emocionais do ouvinte. Impulsos rítmicos originam-se no corpo humano, no movimento e mo discurso. Autores e oradores antigos notaram como diferentes ritmos no discurso afetavam a audiência. Quando a retórica principiou a influenciar a composição musical no séc. XVI, compositores rapidamente se deram conta do potencial para expressar emoçōes através do uso de artifícios rítmicos diversos, emprestado dos padróes do discurso. Assim, a interpretação musical também pode influenciar a maneira como estes artifícios são recebidos pelo ouvinte.

PALAVRAS-CHAVE: Retórica musical; Ritmo; Interpretação musical 


\section{EXORDIUM}

No life can exist without rhythm. It is fundamental to the pattern of everything from the cycle of the seasons to the pulsing of the blood through the chambers of the heart. Regular rhythm is bound up with the body's functions and movements: walking and talking, breathing, exercising and working. This paper will attempt to discover how the listener's emotional response can be controlled by various rhythmic patterns, causing the 17th-century poet John Dryden to ask 'What passion cannot music raise or quell?'("quell” meaning "to lower").

\section{RHYTHM}

Sounds of any sort can be consistent and regular, or sporadic and unpredictable. They can be formed in patterns which can be repeated, or which are only heard once. Each of these modes of sound can engender a particular feeling in the hearer, subconsciously measured against the regular rhythm of the body.

The first discipline a child learns is rhythm. Clapping songs and nursery rhymes instils a sense of inevitability and security about the next event. The child knows what is going to happen. He uses his experience of what happened previously to predict what will happen next. Nursery rhymes use easily-remembered repeated patterns in playful songs about sheep and spiders. Nursery songs are often about people falling to their deaths from tops of hills and walls and so offer an early lesson in what life has to offer. The horror of the events in the songs is mediated by the regular and reassuring rhythm used to describe them.

Roger North, an important musical commentator of the late 17 th century, observed that a regular rhythmic event such as the tolling of a bell is soothing, reassuring, but irregular rhythms are upsetting, even shocking, as the banging of a door in the wind. Unpredictable sounds engender insecurity. North describes what happens in music when several different rhythmic patterns sound simultaneously, as in a fugue, but are arranged around a regular pulse. He found it not confusing 
but satisfying, and enjoyed the mixture of logical patterns which interacted with each other in agreement or opposition.

In speech, Cicero describes anything that can be measured by the ear as rhythm. Cicero said that to present ideas without order and rhythm is to be speechless. The ear receives pleasure from and is charmed by rhythm. Rhythmic words satisfy the understanding. So the combination of sound and rhythm feed both reason and sensation, fulfilling rhetoric's purposes to provide information and then persuade by the use of emotional devices. Cicero says rhythm is a trick which can be used to catch the ear. It knits sentences together, it looks for what is well proportioned, it is recognized by feeling and it polishes the words. A variety of rhythms forestalls monotony. So rhythm gives pleasure, intellectual satisfaction and order whenever it is present.

The principal Roman authority on speaking, Quintilian, says the best judge of rhythm is the ear, which appreciates fullness of rhythm or feels the lack of it. It is offended by harshness, soothed by smooth rhythms and excited by impetuous movement. Even the untrained ear derives pleasure from it. Quintilian maintains that, as a general rule, if the choice were forced upon him, he would prefer rhythm to be harsh and violent rather than nervous and effeminate. Rhythm should not be continued with the same recurrence of feet. In other words, in oratory our patterns of rhythms should be broken up and varied to maintain the interest of the listener, a point to which we will return in a musical context.

Rhythm is a fundamental element of music, the origins of which are difficult to separate from either speech or dance. Rhythmic effects are described in the classical rhetoric books already mentioned by Cicero and Quintilian, which would have been familiar to the Florentine cameristas of the 16th century. In France the Baif academy attempted to reproduce songs in Greek rhythms, but unfortunately the French language did not lend itself to being squeezed into the classical rhythmic patterns, so there were some very strange results. In 1567 Baif invented a new poetic style, the vers mesurés à l'antique. Collaborating with the musicians Courville and le Jeune, an attempt was made to use ancient rhythms to establish moral and spiritual effects, with questionable results. This approach to combining written textual rhythms with 
music survives in the measured French recitative found in the operas of Lully and Rameau.

\section{RHYTHM AND MUSIC}

In Italy, Monteverdi's list of considerations for performance or 'manners of playing' consists of the oratorical, that is the text, the harmonic, in combinations of notes, and the rhythmic. Melody is conspicuously absent from his view of performance. Why should this be?

Aristides Quintilian, a Greek source on music from possibly the 2 nd century, known through its Latin translation to many musicians of the 17th century, describes melody as lax and inert, yet when combined with rhythm, melody becomes hard-edged and active. He says that without rhythm melody is obscure and confusing, and that it is rhythm that makes clear the character of the melody. So rhythm adds meaning, structure and logic to pitch. The ancients describe rhythm as male, melody as female, on the grounds that melody is inactive and without form. Rhythm moulds it and determines the order, playing the part of the maker.

Ancient musical rhythms were derived from texts, reflecting the meters of verses which were sung and danced. Dance gives us the 'lift' and 'step' of arsis and thesis, up-beat and down-beat, corresponding to the lifting and lowering of the foot, going with or against the force of gravity. When unequal, the down beat was the longer, therefore stronger, stressed beat. The ancients clapped or body slapped when dancing, and clappers and castanets were used for emphasis. The aulete (wind player) had a special clapper shoe because his hands would be otherwise occupied. In the early fourth century BC lecturers on music had a board beneath their feet to tap rhythms. Quintilian describes a kitharode (poet with lyre) marking time with his foot.

Aristides writes of rhythms where the more restful are those beginning from theses [the down beat], which restrain the heart at the outset; those beginning from arses [upbeat] are agitated. [...] those having short rests are more artless and petty, and those having longish rests are more magnificent. Rhythms prescribed in equal ratio are more graceful because of evenness...[.] Of rhythms in equal ratio, those arising 
through shorts are fastest and hotter, those through longs, slower and restrained. Because of this, we see that the shorts are useful in the war dances, and the longest in the sacred hymns [...] composing the heart of men by equality and length into orderliness, as this is the healthy condition of the soul.

The Greeks believed that music exerted a moral effect on the soul. Greek education taught gymnastics for the body and music for the soul and spirit. Music would have encompassed the study of poetry, whose rhythmic content would have been understood and felt by the educated Greek and transferred automatically to the musical context.

Where there was text, Plato decreed in the Republic, music must ideally follow the words, an idea quoted by and central to Monteverdi's approach to composition. The chosen rhythmic units make the character obvious, forming sequences, which are then themselves repeated, either exactly or with small differences. In the ancient situation it is obvious that the poet and the composer were one and the same.

The use of two syllable lengths, long and short, produced a binary system yielding patterns which in poetry were used in a predictable way, either long short short (dactyl) or short short long (anapaest). These two were the most common meters in antiquity and could be arranged in any order according to need. Appropriate meters were chosen to be in decorum with form, so for example, the anapaest would be the natural rhythm for marching in a double foot unit. Aristides gives a warning to orators: inadvertent production of regular verse meter in a speech is comic and could give rise to derision or laughter in the audience. Aristotle says the fully metrical in speaking is too artificial and distracting as it makes one expect the recurrence of a similar rhythmic pattern. He says the speech must have rhythm, but not metre, or then it would become a poem. Here we have a clear division of the appropriate use of rhythm: for dance, or for speech (think of recitative). Dance has regular repetition of rhythmic units. Counterpoint has overlapping of arguments, quarrelling or agreement of parts. The rhythmic character of the fugal idea or musical motif is important and provides a jumping off point to introduce contrasts and development. In this sense, counterpoint could be compared to oratory. Dance, is regular and unified in intention, so 
more like poetry. Oratorical speeches (as counterpoint) need to be irregular, in both phrase lengths and amount of movement, with frequent changes of affect, surprise events, strong contrasts and variety. Dionysus of Halicarnassus describes oratory as haphazard and varied in rhythm.

Quintilian supports this theory and says that the orator who is detected in a studied adherence to regularity will cease to carry conviction or to stir the passions and emotions. The judge will refuse to believe him or to allow him to excite his compassion or anger if he thinks that he has leisure for this species of refinement. It will therefore be desirable from time to time that in certain passages the rhythm should deliberately dissolved.

Music for dance will be more regular, follow predictable patterns with a reasonably consistent affect for each dance, and in music of the 16th to 18th centuries, the variety necessary for rhetorical affect will probably be represented by other elements such as harmony or instrumentation. Musicians need to be able to apply these distinctions which reflect style and form: the regularity of dance or the irregularity of counterpoint in emphasis and phrasing. Too much attention to the bar-line in non-dance music can result in solecisms of impropriety, and misunderstandings in meaning.

Now, to the affects of various rhythms. In general, long syllables are more serious than short, which Quintilian describes as suitable for comic situations. Many short syllables used consecutively may be used for comic affect, as in patter songs. The iambic (short long) and trochaic rhythms (long short) were the running feet. Aristotle says the trochee is too rumbustuous and bouncy. Quintilian describes the affect of short long as vigorous ascent, showing effort, and the long short for descending, easily tripping downhill. This affect can be observed in much 17 th-century music, frequently occurring combined in a mirror form in minuets: short long, long short.

Cicero says "The spondee consists of two long syllables, and seems rather heavy and slow; still it has a steady movement that is not without dignity". Spondaic rhythms with their long slow syllables were used for invocations of gods, which we might call hymns, libations (sponde), and religious solemnity. Quintilian tells how Pythagorus on one occasion, when some young men were led astray by their passions to 
commit an outrage on a respectable family, calmed them by ordering the piper to change the strain to a spondaic measure, and he says nurses select a special tune with calming rhythm to entice their little charges to sleep.

The dactyl (long short short) was grand, noble and stately. The more long syllables you had the more dignified, calm and serious the speech or song. This rhythmic affect is found in some great symphonic classics: Beethoven (slow movement of 7th symphony), Schubert (slow movement of 'Great' C major symphony and string quartet in $\mathrm{D}$ minor 'Death and the Maiden').

Rhythms were chosen to convey a mood, so composers might choose to use the rhetorical tool of contrast and variety to place calm and steady against quick; dignified and grand against undignified or lowly; manly and stirring against effeminate or sensuous.

Although triple time is usually less serious, the molossus where three long heavy beats make up a foot is elevated and dignified. Bach's contemporary, Johann Mattheson says:

The molossus, which gets its name from hard toil or from battles, in which there is no small amount of work, has three long syllables or sounds, and expresses arduousness or something which is hard work. The majestic pace of this foot can also serve quite well for a march or procession, especially with drums (note - a march in triple time). The molossus is little used in other cases, and is least suited for lively pieces or dances; but is much better used for very serious, sad, or melancholy circumstances. (MATTHESON, 1991 [1739], II, 6, 26)

\section{Mattheson continues:}

In instrumental concertos this tone-foot is often interpolated for variation between an allegro and presto, in short movements with few measures, Staccato, that is, where the strokes of the violin bow must be well detached from one another, as if rests stood between the notes. (MATTHESON, 1991 [1739], II, 6, 27)

We find many examples of the molossus in Italian concertos by Corelli, Handel and Vivaldi. The exact degree of separation will produce the required affect, but excessively short, 
spikey notes will fail to satisfy the demands of the character of the heavy, arduous molossus.

\section{PERFORMANCE: TEMPO AND ARTICULATION}

Having established an emotional response for various feet, how might the performance influence the effectiveness of the rhythmic unit?

For the ancients, speed was limited by the rate at which words could be uttered. Not gabbling, but not slower than appropriate speech. So, in music in the rhetorical style we should avoid excessively fast or slow tempi. Words or notes need to hang together in defined groups to be comprehended by the listener. Tempo was chosen to suit the style and purpose of the speech. Quintilian describes how a vigorous dispute demands speed, an exposition or statement of fact a slower rhythm.

Jean Jacques Rousseau, in his musical encyclopedia, describes the varying affects of playing the same type of music at different speeds, first quadruple then triple:

Very slowly-moving quadruple meter is sad; at a slightly faster speed the effect is merely solemn; a little less slowly still and the effect is grand and majestic; taken at an allegro it becomes stately and proud; faster still and it becomes impetuous, uncontrolled and furious. Triple meter never loses a certain quality of sweetness whatever the speed at which it is taken. Slow triple meter expresses an affecting sadness; less slowly, tenderness; a little more quickly, contentment; faster still, gaiety but never anger. (ROUSSEAU, 1768, p. 281-285)

Tempo: the 17th century. A basic tactus or pulse will be 'ordinary', tempo ordinario. This pulse is filled with more or fewer notes or harmonic changes according to the affect. The rhetorical style will never demand very slow or very fast (except for display purposes, for example in instrumental divisions) but the pulse should remain constant, and is filled with many or not very many notes to sound slow or fast. If the time signature changes, proportion shows how going from duple to triple, the triple would sound faster, more tripping, than the serious duple. They retain their different character within the same pulse. Slowing up at the transition points will only destroy this relationship and make it impossible to achieve. 
Tempo: the 18th century. How fast is the beat? Quantz recommends the most useful guide - the hand of a healthy man, which revives the ancient concept of the body rhythm to determine pulse. He says look at the fastest notes to determine the speed. 8 notes to a pulse are about the most you'll find and 80 is normal for a pulse (depending on the written note values). Quantz recommends adopting a tempo which represents a general walking pace, with a bit slower or a bit faster for various 'slow' or 'fast' movements. He warns virtuosi no to 'abuse your facility by playing too fast!' Also, your pace should be adapted to the acoustic, faster in a tapestried room, slower in a resonant room, and take into account the closeness or distance of the listeners.

Quantz notes that body pulses beat more slowly in the morning, before meal times and slower in a person inclined to melancholy. Apparently, it was common knowledge to Quantz's readers that a piece repeated once or more, particularly a fast piece, is played a little faster the 2 nd time, in order not to put the listeners to sleep. He says this enables the music to take on a more lively guise and arouses the listeners' attention.

In dance music, he describes how each type requires its own tempo which is "not as arbitrary" as in Italian music. If dancers and orchestra can always arrive at the same tempo, they will avoid much ill humour. He says it is well known that most dancers understand little or nothing of music, and frequently do not know the correct tempo themselves. They regulate themselves by the mood at that moment, or by their ability.

Groups of words which form feet should belong together, and the use of excessive articulation makes understanding difficult for the listener. The choice of articulation should depend on the place, the degree of connection and separation, and speed. Dionysus of Halicarnassus says the polished style of composition "does not intend each word to be viewed from all sides, nor that every word shall stand on a broad firm base". He requires that "words shall keep on the move, swept forward and riding along on top of one another, all sustained in their movement by mutual support, like the current of a stream that never rests". Quintilian also uses the watery comparison when he says good oratory should pour like a torrent, 
not a trickle. Cicero says it shouldn't wander along vaguely like a river.

Moving now to the 18 th century, the most important musical source for the use of classical rhythms is Johann Mattheson. He gives us musical examples of all the standard classical feet already mentioned, with their affects. Mattheson also discusses phrase structures. As we have seen already, by comparing dance and counterpoint with poetry and oratory, phrases will either be regular, expected and predictable, or irregular and surprising. Equally balanced phrases (with the same rhythm, the isocolon) often appear in oratory as question and answer, or two balanced points of view. Mattheson illustrates this point with a minuet. A short argument may be constructed from 2 equal short phrases (on the one hand, on the other hand) followed by a longer one often double the length, concluding with a cadence. 2 measures, 2 measures, 4 measures, a standard pattern in the minuet, and found frequently in other dances.

\section{INSTRUMENTAL LANGUAGE}

Should instruments always imitate speech? Monteverdi noted that rhythms with continuous shorts didn't seem to feature in music of the past, and invented his agitated 'concitato' style to represent anger. This is derived from Plato's description of "the voice and accents of a man going bravely into battle" using the Pyrric foot which was used for war dances. Monteverdi describes the affect he achieved, to express anger and vexation, but notes that the voice can not attain the velocity of the instrument. This is an important watershed for instrumental music. Now instruments began to acquire their own language, independent of the voice, and could play notes faster than the voice could speak, creating new exciting effects. For the benefit of composers, Mattheson describes other compositional devices which are difficult or unnatural for voices. These include very large intervals, fast repeated notes and fast arpeggios.

Equal arsis and thesis promote an orderly feeling but unequal rhythms are more disturbing. Quintuple time units are unusual in western music and are described by the ancients as unsettling. For use in French overtures the five part unit, the 
paeon, has been rationalized for use in our system of notation. We don't find unadjusted five-unit rhythms in music of the 16 th to 18 th centuries.

Quantz describes gaiety, which is represented by short quarter notes in alla breve; he says majesty is represented by long notes during which other parts have short notes; majesty also, by dotted notes which should be sharply attacked and lively, the long notes held long. C.P.E. Bach describes the performance of dotted notes as dependent not on any mathematical rule, but on the affect required. Sharply dotted will be tense, less dotted more relaxed.

My final rhythmic tool, syncopation, is described by Quantz as expressing flattery, but there are other applications and uses: the bouncy reactive and the impatient anticipatory one. Emphasizing the second part of the syncope (condemned by Leopold Mozart when done with the bow) will negate the affect of the rhythmic figure. Syncopation can usually be identified by the appearance of tied notes. A tie onto a strong dissonance indicates an anticipated strong beat, which should be attacked and sustained on to the dissonance. The reactive type should not be stronger than the thing it is reacting to, usually a chord on a strong beat of the bar. Depending on the context and mode of delivery, syncopation can drive the music along or instil a gentle soothing pulse.

\section{CONCLUSION}

We take rhythm for granted, but without it the language of music would be difficult to understand. The human body itself gives us rhythm to play with. Let us understand and use its variety as part of the power music has to 'raise and quell' the passions. Rhythm, in partnership with pulse, tempo, emphasis and articulation is an infinitely variable device. It contributes to music's power to persuade, and forms an important tool in our magazine of rhetorical weapons, but only if we understand its purposes and apply that knowledge to our performances. 


\section{BIBLIOGRAPHY}

ARISTOTLE. The Art of Rhetoric. Transl. by E. H. Freese. Cambridge: Heinemann (Loeb Classical Library), 1934.

CICERO. De Oratore. Transl. by E. W. Sutton. Cambridge: Heinemann (Loeb Classical Library), 1942.

HALICARNASSUS, Dionysius of. On Literary Composition. Transl. by W. Rhys Roberts. Cambridge: Heinemann (Loeb Classical Library), 1974.

HOULE, George. Meter in Music, 1600-1800. Michigan: Indiana University Press, 1987.

MATTHESON, Johann. Der vollkommene Capellmeister (Hamburg, 1739). Kassel: Bärenreiter, 1991.

MONTEVERDI, Claudio. Preface to Madrigali Guerrieri. Book VIII (1638). Milano: Ricordi, 1967.

NORTH, Roger. On Music. London: Novello, 1959.

QUANTZ, Johann Joachim. On Playing the Flute. Transl. by Edward Reilly. Boston: Northeastern University Press, 2001.

QUINTILIAN, Marcus Fabius. Institutio Oratoria. Transl. by H. E. Butler. Cambridge: Heinemann (Loeb Classical Library), 1998.

QUINTILIANUS, Aristides. On Music, in three books. Transl. by T. Mathiesen. New Haven: Yale University Press, 1983.

ROUSSEAU, Jean Jacques. Dictionnaire de Musique. Paris: Duchesne, 1768.

TARLING, Judy. The Weapons of Rhetoric. London: Corda Music Publications, 2008.

WEST, M.L. Ancient Greek Music. Oxford: Oxford University Press, 1992. 